UDC 519.866:004.032.2:338.02

JEL Classification: C02, G22, 011

http://doi.org/10.21272/mmi.2019.3-23

Robert Bacho,

D.Sc., University of Nyiregyhaza, Hungary

Rishard Pukala,

Ph.D., The Bronislaw Markiewicz State Higher School of Technology and Economics in Jaroslaw, Poland

Serhii Hlibko,

Ph.D, The Scientific and Research Institute of Providing Legal Framework for the Innovative Development of National Academy of Law Sciences of Ukraine, Ukraine

Nataliya Vnukova,

D.Sc., Simon Kuznets Kharkiv National University of Economics, Ukraine

Peter Pola,

Ph.D., Institute of Economics, Eotvos Jozsef College, Hungary

\title{
INFORMATION MANAGEMENT: THE KEY DRIVER OF THE ECONOMIC SYSTEM'S DEVELOPMENT
}

\begin{abstract}
In the scientific article, an information management model was developed for assessing the influence of regulatory tools on business processes on the example of the insurance market of Ukraine. The main purpose of the research is to determine the role of information management as a key driver of business process development in economic systems (on the example of the Ukrainian insurance market). Systematization literary sources and approaches for solving the problem indicates that the development of innovative tools of public governance for the assessment of the regulatory influence of the state regulatory body on the business processes of insurance market is not completed and requires a more in-depth study. The formation of a system of indicators characterizing the business processes of insurance market, which take into account the influence of the Regulator's tools, is proposed to be implemented in the following sequence: to find out the causal links between the indicators of business processes of insurance market and the measures; to determine the existence of the reaction of business processes' indicators of insurance market to the Regulator's measures, taking into account the time gap, which determines the presence of lags in the process of applying the Regulator's measures; to define and formalize the variability of the business processes' indicators of insurance market under the influence of the Regulator's measures. Then the scale of the state of insurance market was built: firstly, check for normality the distribution of the indicators' values of these markets; secondly, in compliance with the distribution law to construct the scale of indicators according to the "three-sigma rule»; thirdly, in the case of nonconformance with the normal distribution law and presence of skewness, the method of "three sigma" may be used, but either the arithmetic mean, or the mode of the variation series, or its median, is taken as the reference point. The relevance of the decision of this scientific problem is that a set of models is developed for establishing causal relationships between the indicators characterizing the business processes of the insurance market and government regulation instruments, which are quantitatively determined, are theoretical and practical basis for their possible application for solving universal modeling problems of causal processes of estimating the influence of the taken decisions at any regulation of business processes. To solve the problem the Granger-test, the expanded Dickey-Fuller test, the Phillips-Perron test and the Kwiatkowski-PhillipsSchmidt-Shin test were applied. Time series distribution on stationarity and construction of vector autoregression models are implemented. In order to evaluate the adequacy of the models, a comparison of values of Fisher's, Student's criteria, determination coefficient and adjusted determination coefficient is used. Jarque-Bera criteria are used to test the model for stationarity, stability. The formalization of cause-and-effect relationships through the postulate of the theory of measurements and the construction of scales is performed. The built interval scales are based on the application of the three sigma rule, which made possible to specify the allowable boundary values of the indicators. The obtained results testify the influence of regulatory tools on the business processes of insurance market, which confirms the correctness of the use of this complex of models for the solution of weakly formalized problems of causal nature of universal type. The proposed innovative model can be used as a methodology for developing a set of rational methods for assessing informational influences of management decisions in production
\end{abstract}

Cite as: Bacho, R., Pukala, R., Hlibko, S., Vnukova, N., Pola, P. (2019). Information Management: the Key Driver of the Economic System's Development. Marketing and Management of Innovations, 3, 297-307. http://doi.org/10.21272/mmi.2019.3-23 
R. Bacho, R. Pukala, S. Hlibko, N. Vnukova, P. Pola. Information Management: the Key Driver of the Economic System's Development

systems or marketing research. The results of the research can be used to evaluate the business processes of any market or system.

Keywords: business processes, Granger test, informational management, informational model, insurance key driver, services market, regulation tools, scaling, vector autoregression.

Introduction. Under present conditions of countries' development, there is a need to revise the existing approaches to state regulation of all systems, in particular, business models of insurance markets (Eichengreen and Dincer, 2011). Countries of the world have intensified the process of transition to various models of state regulation (Cihak and Podpiera, 2006; Nier, et al., 2011), which necessitates an assessment of the state of development of various markets under the influence of existing regulatory tools (Horakova, 2012). In the concepts of ensuring national security in the financial sphere of any country is noted that global crises show the vulnerability of insurance markets and their dependence on external influences (Melecky and Podpiera, 2012), which requires strengthening the protection of the national interests of the state in this area (Frantz and Instefjord, (2012). It's necessary to search universal innovative approaches to improve the regulation directions and measures of influence on business processes development of financial, environmental, security and other systems. The basic hypothesis is the assumption of the existence of causal relationships between the indicators characterizing the market's business processes and state regulatory tools that can be quantified. The secondary hypothesis assumes that for the investigated period (2006-2017) there is an improvement of business processes in the insurance market of Ukraine. Confirmation of these hypotheses through the use of a complex of innovative models will serve as a theoretical and practical basis for their possible use to solve the universal problem of modelling causation processes of impact assessment of made decisions at any regulation of the business processes development.

Literature review. A number of scholars have conducted research into modelling the impact of innovative models on the state of business processes in financial services markets.

Masciandaro D., Quintyn M. investigate the tendency of formation of the structure of financial supervision. Which is characterized by the reconciliation of opposite features: consolidation and specialization were investigated. A political-economic approach was used to explain this trend, where the decision-making process regarding the form of the supervisory regime was linked to the influence of the central bank's institutional setting and the role of political governance. The authors founded that consolidation mainly occurs in countries with high-quality public sector management and little central bank involvement. It was noted that in order to have a comprehensive and refined information base, it is necessary to study in-depth innovative models of supervision: a single model and a horizontal model.(Masciandaro and Quintyn, 2009).

Cihak M., Podpiera R. reviewed theoretical sources and empirical research at the macroprudential level of the process of supervisory bodies' merging in financial markets and determine the potential effects of such bodies' integration. The methodology recognized by IMF was used to evaluate four components: the condition and content of regulatory governance, prudential supervision, prudential framework, regulatory practices, financial integrity/safety net. As a result, it was noted that States with integrated supervisory bodies have greater consistency in the quality of oversight through integrated bodies. But this work is not given the influence of the business - processes' the integration, it is not possible to carry out by using only empirical methods (Cihak and Podpiera, 2006).

Nier E., Osinski, J., Jacome, L.I., Madrid, P. distilled lessons and set out desired principles for effective macroprudential policy arrangements. They identify five key distinguishing dimensions of reallife models: the degree of institutional integration between central bank and financial regulatory and supervisory functions; the ownership of the macroprudential mandate; the role of the government (treasury) in macroprudential policy; the degree to which there is organizational separation of decision making and control over instruments; and whether or not there is a coordinating committee. As a result 

Development

of the research, scientists distill general and more specific lessons that can translate into basic guidance for countries. (Nier, et al., 2011)

Ingves S. noted, in this context, that the Central Banks need information on the quality of collateral provided for central bank credit, the solvency of institutions seeking liquidity support, the state of systemically important institutions, and interconnections between institutions, markets and systems. The scientist also notes that where the central bank is given prime responsibility for macroprudential policy, decision-making structures or procedures will need to provide for the coordinated calibration of monetary and macroprudential policy settings. (Ingves, 2011)

Goodhart C., Schoenmaker D., Tsomocos, D.P determined the conditions of financial stability. For this purpose, the theoretical and practical models, as implemented theoretical issues in practice were considered. The authors emphasized the need to model default in the formation of policies regarding financial stability at the macro-financial level and its relationship with maintaining liquidity. (Goodhart and Schoenmaker, 1995; Goodhart and Tsomocos, 2012),

Hirtle B., Schuermann T., Stiroh K. carried out a research of implementations effects of Supervisory Capital Assessment Program (SCAP), better known as the bank «stress test», and explored the complementarity between macroprudential and mikroprudentsiynym supervision. But researched forecasts of costs were calculated on national basis interests, and were not focused on not focusing on specific business processes or segments. It is concluded that the objectives, approaches and impacts should be more comprehensive and reflective of the macroeconomic and financial sectors under review, including in order to increase the awareness of the supervisory authorities (Hirtle, et al., 2009).

Hlibko S., Vnukova N., Hontar D., Anisimova H., Liubchych A. as the level of interaction between macroprudential supervision and micro-financial regulation, in accordance with the recommendations of Basel II, three methods for measuring the size operational risk was described. These alternative methods in terms of increasing complexity and sensitivity are the Basic Indicator Approach, Standardized Approach and Advanced Measurement Approach. These methods are analyzed as ways of information management for decision making by bank boards (Hlibko, et al., 2019).

Ponomarenko V., Vnukova N., Kolodiziev O., Achkasova S. described separate methods of information management to eliminate obstacles in the development of the economy. The theoretical provisions have been substantiated, methodological and practical recommendations have been developed to assess the impact of state regulation and supervision on the development of a risk-oriented system of counteraction to anti-money laundering, terrorist financing and financing of the proliferation of weapons of mass destruction in Ukraine in order to achieve this goal. The impact of tools and actors on the priority goals of developing a risk-oriented system is recognized. Also, the priority scenario of development using the hierarchical method of analysis was determined (Ponomarenko, et al., 2019).

The listed scientific sources are more devoted to macroeconomic research. Therefore, it is important to refer to the methods of managing individual business processes, which is planned in this study.

Methodology and Research Methods. The aggregate of statistical information for the research is obtained by generalizing the primary information collected and published on the official website of the body that regulates the financial services markets in Ukraine (Regulator) for 2006-2017.

The formation of a system of indicators characterizing the business processes of insurance markets is due to the need to establish a causal relationship between specific business indicators of the market and existing regulatory tools that are at the disposal of the Regulator. The formation of a system of indicators of business processes at the insurance market, which takes into account the influence of the Regulator's instruments, is proposed to be implemented in the following sequence: 1) to find out the causal links between the indicators of business processes of insurance market and regulatory measures (influence); 2) to determine the existence of the reaction of indicators of business processes of insurance market to the Regulator's measures, taking into account the time gap, which determines the presence of 

Development

lags in the process of applying the Regulator's measures; 3) to define and formalize the variability of the indicators of business processes of insurance market under the influence of the Regulator's measures.

In consequence of the foregoing the production of a system of indicators of business processes of the insurance market, in view of the above-mentioned objectives, is proposed to be done in the following order. Stage 1 - summarizing the list of indicators of business processes of insurance market; stage 2 carrying out the Granger test (Granger, 1974; Granger, 1983) for the causal relationship between the indicators of business processes of insurance market and the Regulator's instruments, taking into account the variability of the results in time (time lag); stage 3 - time-series validation for stationarity by the expanded Dickey-Fuller test (Dickey and Fuller, 1981), Phillips-Perron test (PP-test (Phillips and Perron, 1988), and the Kwiatkowski-Phillips-Schmidt-Shin test (KPSS-test (Kwiatkowski, et al., 1992) to resolve the ambiguity of the interpretation of the Dickey-Fuller and Phillips-Perron tests' results. According to the test results, the time series are distributed to the stationary and non-stationary ones. As a result of detecting stationarity of the time series innovative vector autoregression models (Ren, et al., 2013) were constructed. If it is found that the time series is non-stationary, it is necessary to carry out stage 4 . Stage 4 - checking the time series with the same integration order for cointegration based on the Johansen procedure. If there is no cointegration, it is possible to apply vector autoregression models in the first differences. In the presence of cointegration of time series, error correction models (Lebo and Kraft, 2017) and vector autoregressive models at levels (Ren, et al., (2013) are used. Based on the official report of the Regulator, the primary set of indicators characterizing the state of the insurance market of Ukraine has been formed. For revealing of causal dependencies of indicators of the state of insurance market and Regulator's tools in the formation of a system of indicators of the state of insurance market, the authors proposed the use of Granger causality test (Granger, 1974). The introduction of this tool within the framework of the study is justified by the primary need for confirming or refuting the hypothesis of the existence of a causal relationship between the indicators, but not the definition of the tightness of the relationship between the variables of the correlation analysis.

The dependence of the Regulator's measures and indicators of business processes of insurance market, according to Granger (Z), is related to the verification of possible mathematical descriptions of economic and other random processes presented as follows (formula 1) (Damodar, 2009):

$$
z_{t}=\sum_{j=1}^{p} \alpha_{j} z_{t-j}+\sum_{j=1}^{p} \beta_{j} y_{t-j}+\varepsilon_{1 r} y_{t}=\sum_{j=1}^{p} c_{j} z_{t-j}+\sum_{j=1}^{p} d_{j} y_{t-j}+\varepsilon_{2 r},
$$

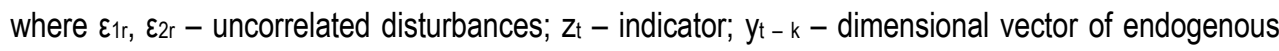
variables.

The essence of the Granger causality test (Granger, 1974; Granger, 1983) is to verify the significance of the coefficients $\alpha_{j}, \beta_{j}, c_{j}, d_{j}$ (Damodar, 2009), i. e.:

- if $\alpha_{j}$ is statistically significant as a group, and $\beta_{j}$ is insignificant, then by Granger - Y1 affects 01 , that is, it causes the change of its value;

- if $\beta_{j}$ is statistically significant as a group, and $\alpha_{j}$ is insignificant, then inverse relationship is observed $\mathrm{O} 1 \rightarrow \mathrm{Y} 1$;

- if $\alpha_{j}, \beta_{j}, c_{j}, d_{j}$ are simultaneously statistically significant, then there is a bi-directional causality;

- if $\alpha_{j}, \beta_{j}, c_{j}, d_{j}$ are statistically insignificant at the same time, the correlation is absent.

The interdependence of the business process' index of the insurance market by the parameter 01 (formula 2) and the Regulator measure Y1 (formula 3) according to the test is carried out in the following sequence:

$$
01=\operatorname{gdp}_{0}+\sum_{j}^{p} \alpha_{j} \mathrm{y} 1_{t-1}+\sum_{j}^{p} \beta_{j} 01_{t-1}+\varepsilon_{1 r}
$$


R. Bacho, R. Pukala, S. Hlibko, N. Vnukova, P. Pola. Information Management: the Key Driver of the Economic System's Development

$$
\mathrm{Y} 1=\text { tend }_{0}+\sum_{j}^{p} c_{j} \mathrm{y} 1_{t-1}+\sum_{j}^{p} d_{j} \mathrm{O} 1_{t-1}+\varepsilon_{2 r}
$$

where 01 - 028: 01 number of contracts, except contracts for compulsory insurance against traffic accidents; $\mathrm{O} 2$ - including with insured individuals; $\mathrm{O} 3$ - Number of contracts on compulsory personal insurance against traffic accidents; $\mathrm{O} 4$ - Gross insurance premiums; 05 - Gross insurance premiums for life insurance; 06 - Gross insurance payouts; 07 - Gross insurance payouts for life insurance; 08 Level of gross payouts, \%; 09 - Net insurance premiums; 010 - Net insurance payouts; 011 - Level of net payouts, \%; 012 - Paid for reinsurance, million UAH; 013 - Paid for reinsurance to resident reinsurers, million UAH; 014 - Paid for reinsurance to non-resident reinsurers, million UAH; 015 Payments reimbursed by reinsurers, million UAH; 016 - Payments reimbursed by non-resident reinsurers, million UAH; 017 - Payments reimbursed by non-resident reinsurers, million UAH; 018 Insurance premiums received from non-resident reinsurers, million UAH; 019 - Payments compensated for non-resident reinsurers, million UAH; O2O - Volume of formed insurance reserves, million UAH; O21 - Volume of formed insurance reserves for life insurance, million UAH; O22 - Volume of formed insurance reserves - technical reserves, million $\mathrm{UAH}$; $\mathrm{O} 23$ - Total assets of insurers, million UAH; $\mathrm{O} 24$ - Assets defined in art. 31 of the Law of Ukraine «On Insurance» for reserves provision, million UAH; O25 - The amount of paid-in statutory capital, million UAH; O26 - Number of institutions (insurers) in the market; O27- The share of the first three largest companies in the market (TOP-3), \%; O28 - Number of consumers of the insurance market. $Y 1$ - Y8: $Y 1$ - Number of inspections (total); $Y 2$ - Proceeds from fines, thousand UAH; Y3 - Number of revoked and suspended licenses; Y4 - Number of excluded financial institutions; $Y 5$ - Reports on money laundering; Y6 - Number of legal acts drafted; Y7 Number of regulator's orders accepted; $Y 8$ - Number of people employed in regulation.gdp, tendo constants; - including with insured individuals.

As the basis of the Granger test was put the null hypothesis that the number of inspections does not affect the number of contracts, except contracts for compulsory insurance against traffic accidents. This statement is rejected or accepted based on Fischer's F distribution (Damodar, 2009). To reject the null hypothesis at the 5 percent significance level is necessary that $p$-value for the corresponding pair of indicators were within 0.05 . This hypothesis is applied for each indicator that characterizes the Regulator's measures (Y1-Y8), and indicators of the state of the insurance market (01-O28). Logarithms of time series values were taken not only for smoothing them. The advantage of such approach is that the logarithmic difference is an approximation of the growth rate of the indicator in order to take into account the multiple effects of variables (Dritsaki et al., 2004). Also, logarithmic transformations can form a stationary time series (Box and Jenkins, 1976).

In order to quantitatively express the correlation between the indicators of business processes of insurance market and the Regulator's measures in the short and long term prospects, and to confirm the cause-effect relations identified by the Granger-test, in the research a third stage of the formation of the system of indicators of insurance market's state was introduced, which involves checking the time series of the market situation and Regulator's measures for stationarity.

To address the issue of assigning a series to a stationary or non-stationary one is used the hypothesis that there is at least one unit root in the autoregressive polynomial, in the case of assigning the time series to the non-stationary. To identify this unit root, most researchers in practice use the expanded method of Dickey-Fuller (Augmented Dickey-Fuller test, ADF (Dickey and Fuller, 1981), Arltova and Fedorova, 2016), which estimates by means of the least-squares method. The Dickey-Fuller statistics has a non-standard distribution (Arltova and Fedorova, 2016), therefore it requires appropriate special tables that are empirically built using the Monte Carlo method. These tables contain an element of uncertainty, so there are two critical values - the upper and lower one. If the estimated value of t- 

Development

statistics is less than the lower acceptable critical value, the null hypothesis about the presence of a unit root is rejected and a conclusion is made about the stationarity of $\{x t\}$. The values in the table are supposed to be negative. And conversely, if the estimated t-statistics is greater than the upper permissible value of the critical value, then the null hypothesis is accepted. Between the upper and lower limits is the uncertainty zone. Such a table is constructed and distributed by the number of observations, but if another observation number is used in the sample, the MacKinnon formula is used (MacKinnon, et al., 1999). To refine the results of the study on the basis of the Dickey-Fuller test and to determine the specification of the series of dynamics of effectiveness indicators of sustainable development of economic performances which change with time, the Phillips-Perron test (Phillips and Perron, 1988) and Kwiatkowski-Phillips-Schmidt-Shin test (Kwiatkowski, et al., 1992) are used.

Based on the types of time series of the parameters characterizing the business processes of insurance market and the Regulator's measures, the next stage of formation of a system of indicators of business processes of insurance market is realized, which allows to reveal the variability of the business processes indicators of these markets under the Regulator's measures and the factors of influence in numerical expression. To summarize the results of time series research for dependencies on time and cyclic fluctuations factors were used ADF-statistics, PP-statistics, KPSS-test and it is determined whether the time series of indicators of the market's state is stationary.

To implement this for the stationary time series of indicators of the insurance market's state, the construction of vector autoregressive models (Ren, et al., 2013) has been applied, which can be represented by the formula (4):

$$
y_{t}=A_{1} y_{t-1}+\cdots+A_{p} y_{t-p}+\mathrm{Bx}_{t}+\varepsilon_{t}
$$

where $x_{t}-d$-dimensional vector of exogenous variables; $A_{1}, \ldots, A_{p}$ i $B$ - matrices of the coefficients to be assessed; $\varepsilon_{t}$ - residual perturbation vector.

In the following formulas (4-6) are similar to formulas (1-3) of the interpretation of indicators.

The following characteristics are used to assess the adequacy of the model: comparison of values of Fisher's, Student's criteria, determination coefficient and adjusted determination coefficient. The JarqueBera criteria (Thadewald and Buning, 2007) were used to test the model for stationarity, stability, and previous researches were supplemented by the test to detect the distribution of inverse AR-polynomial roots and by the function of pulsed feedback and dispersion decomposition. The main criteria for selecting a more reliable model that characterizes the influence of the Regulator's measures on the insurance market are the Akaike information criteria (AIC - Akaike Information Criteria) (Akaike, 1973; Burnham and Anderson, 2002) and Schwarz criteria (Schwarz, 1978). The best model is selected for a minimum of Akaike and Schwartz values (Gayawan and Ipinyomi, 2009).

In order to detect the long-term correlation between the Regulator's measures and the parameters of the financial services markets, for the time-dependent time series, i.e. non-stationary series, the Johansen procedure (Johansen, 1991) was used. The formalization of these correlations has been simplified to regression analysis. Detection of significant relationships between the parameters characterizing the business processes of insurance markets and the Regulator's measures is due to the use of the Chaddock scale (Chaddock, 1925). According to the scale, the evaluation of the determination coefficient in the range from 0.5 to 0.7 characterizes a noticeable strength of the relationship.

Having formed a system of indicators characterizing the insurance market's business processes and identified the causal relationships between them and the Regulator's instruments, these relationships were formalized and determined the business processes of the insurance market in terms of regulation. For this the postulate of the theory of measurements was used, since for any empirical system it is always possible to construct a scale, and the corresponding scale values will be determined with the 

Development

accuracy of an arbitrary monotonic increasing transformation. Consequently, these transformations are acceptable for those scales on which elements of the empirical system are represented by a numerical system. The application of the scaling method involves several steps: 1) creation of an empirical system of manifestations of investigated systems and fixation of types of relations between them; 2) data analysis, depending on the results of which a numerical system is built, which is the basis of one of the scales' types. Based on the results of the study above, an aggregate sample of indicators characterizing the state of the insurance market and taking into account the influence of the Regulator's measures is formed.

To build the scale of business processes of insurance market is necessary: firstly, check for normality the distribution of the indicators' values of these markets; secondly, in compliance with the distribution law to construct the scale of indicators according to the «three sigma rule»; thirdly, in the case of nonconformance with the normal distribution law and presence of skewness, the method of «three sigma» may be used, but either the arithmetic mean, or the mode of the variation series, or its median, is taken as the reference point. In the case of right skewness is suggested the correction factor represented by formula (5) and the left-hand skewness by formula (6), which is taken into account when constructing interval scales.

$$
\begin{aligned}
& k_{r}=\frac{M-M_{0}}{M \times n} \\
& k_{l}=\frac{M_{0}-M}{M_{0} \times n}
\end{aligned}
$$

where $k_{r}$ - correction factor; $M$ - median of the variation range of indicators' distribution; $M_{0}-$ mode of the variation range of indicators' distribution; $n$ - number of scale division to the left and right of the median.

Taking into account the correction factor's effect on the range of values, the scale of business processes' indicators of insurance market in the case of right-hand skewness will look like: ( $x_{\text {avg. }}-$ $\left.3 \sigma k ; x_{\text {avg. }}+3 \sigma(k+1)\right)$, in the case of a left-hand skewness somewhat the reverse $\left(x_{\text {avg. }}-\right.$

$\left.3 \sigma(k+1) ; x_{\text {avg. }}+3 \sigma k\right)$. Investigating the indicated sample of indicators, according to the results of the calculations, it was found that most of the indicators of business processes of insurance market have an asymmetric distribution, since the condition of symmetric distribution is equality of the mode, the median and the mean values.

To determine the significance of the asymmetry the skewness coefficient is calculated, which, in contrast to the relative asymmetry index, allows more accurately estimate the asymmetry's significance, and to interpret the obtained results. According to the rule, if the skewness coefficient in modulus exceeds 0.5 , then the asymmetry should be considered as significant, if below this indicator, then asymmetry can be neglected.

When constructing an interval scale with the application of the "three sigma" rule, in case of righthand skewness the scale has mainly the range of values $(M-3 \sigma k ; M+3 \sigma(k+1))$, in case of lefthand skewness somewhat the reverse $(M-3 \sigma(k+1) ; M+3 \sigma k)$. According to the calculations obtained, it was found that most indicators have asymmetries, therefore, a correction factor for them is calculated.

Taking into account the results of calculations, having determined the number of intervals (scale divisions), based on the Sturges' formula (Sturges, 1926), and defined the linguistic filling of the levels of the insurance market's business processes, based on the relevance of studies of the scale of the states of markets and systems, with the corresponding number of division of the scale, interval scales were 

Development

constructed for assessing the state of the insurance market for each indicator at five levels of innovative development: critical, low, satisfactory, medium, high.

Thus, an innovative tool is developed for assessing the state of business processes at insurance market by constructing interval scales based on the application of the three sigma rule, allows to determine the state of business processes at this market by defining the allowable boundary values of the indicators.

Results. Taking into account the peculiarities of business processes of insurance market and its parameters, causal relationship between indicators of the insurance market's state and the results of implementation of Regulator's measures were analyzed. By confirming or refuting the hypothesis of the existence of cause-effect relationships between variables, a system of indicators characterizing the insurance market's business processes is formed, taking into account the influence of the Regulator's actions and factors of influence, without quantitative expression A fragment of calculations of business process parameters by formulas $(1-3)$ is presented in Table1.

Table 1. Causal relationship between Regulator's measures and insurance market indicators

\begin{tabular}{|l|l|l|l|}
\hline Number of lags $\mathbf{= 1}$ & \multicolumn{1}{|c|}{ Number of lags $\mathbf{= 2}$} & \multicolumn{1}{|c|}{ Number of lags $\mathbf{= 1}$} & Number of lags $\mathbf{= 2}$ \\
\hline $\mathrm{Y} 1 \rightarrow 04$ & No relation & $\mathrm{O} 4 \rightarrow \mathrm{Y} 2$ & No relation \\
\hline $\mathrm{Y} 1 \rightarrow 022$ & No relation & $\mathrm{O} 5 \rightarrow \mathrm{Y} 7$ & No relation \\
\hline No relation & $\mathrm{Y} 1 \rightarrow \mathrm{O} 26$ & $\mathrm{O} 6 \rightarrow \mathrm{Y} 4$ & $\mathrm{O} 6 \rightarrow \mathrm{Y} 4$ \\
\hline $\mathrm{Y} 2 \rightarrow 09$ & No relation & No relation & $\mathrm{O} 6 \rightarrow \mathrm{Y} 5$ \\
\hline $\mathrm{Y} 2 \rightarrow 014$ & No relation & No relation & $\mathrm{O}$ \\
\hline
\end{tabular}

Sources: complied by authors.

Implementation of the defined stages allowed to reveal the dynamics of changes in the indicators parameters, which characterize the business processes of insurance market, depending on the changes in the Regulator's measures, and vice versa, the change in the values of the Regulator's measures depending on changes of parameters characterizing the insurance market's business processes; determine the significance of the factors influencing the dynamics of each variable. In accordance with the calculations carried out, business processes at the insurance market cause the change of the Regulator's measures in the following way: 1) increase of gross insurance premiums leads to an increase in proceeds from fines; 2) increase in net insurance premiums leads to a decrease in the number of people employed in regulation; 3 ) increase in net insurance payouts (per one mean-square deviation) results a decrease in the number of excluded financial institutions and money laundering reports sent to the Regulator; 4) growth of the amounts paid for reinsurance by non-resident reinsurers forms a declining trend in the number of revoked and suspended licenses, money laundering reports and people involved in regulation; 5 ) increase in payouts reimbursed by reinsurers leads to a reduction in money laundering reports; 6 ) increase in the amount of compensation paid by non-resident reinsurers, promotes an increase in the number of inspections by the Regulator and developed regulatory acts; 7) growth of the amount of compensation paid for non-resident reinsurers forms a decrease in the number of money laundering reports sent to the Regulator; 8) the volume of the formed insurance reserves contributes to the reduction of the proceeds from fines; 9) increase of the insurance reserves leads to an increase in the number of revoked and suspended licenses and people employed in regulation; 10) increase in the paid-up statutory capitals causes the formation of declining tendencies in the number of money laundering reports sent to the Regulator; 11) increase in the number of consumers at the insurance market determines the growth of the number of people involved to regulation, with their gradual decrease in the analyzed period. 

Development

Based on the results of the Granger test, the following relationships between the Regulator's measures and the insurance market's business processes (time series of which are not stationary) are formalized and confirmed. The number of regulator's orders leads to changes in the volume of the existing insurance reserves for life insurance (by 55\%) and total assets of insurers (by 53\%). The change in the volume of insurance reserves for life insurance by $53 \%$ determines the number of revoked and suspended licenses. The total assets of insurers form $58 \%$ of the number of Regulator's inspections, $66 \%$ of the number of cancelled and stopped licenses and $78 \%$ of money laundering reports. The number of consumers of the insurance market by $76 \%$ forms the number of orders accepted by the Regulator. The need for calculations and the establishment of causal relationships formed the basis for determining of business processes of the insurance market in terms of state regulation. In accordance with the built interval scale for assessment of business processes of the insurance market, a change in its state for the period from 2005 to 2017 is determined. An instability in the business processes of the insurance market is observed due to the transition from critical to low and from low to satisfactory level, etc. In 2013-2017 the state of business processes of the insurance market has changed qualitatively, reaching the state of moderate innovative development. The obtained results testify to the significant influence of Regulator's regulatory tools on the business processes of the insurance market of Ukraine during the investigated period, in particular, a substantial improvement of the indicators is observed for the period 2014-2017. The researches show that the level and applied model of state regulation, as well as the priorities of state regulation, significantly influence the development of the insurance market. The proposed innovative model of assessment of regulatory tools' impact on the business processes can be applied for any financial services market (bank and non-bank), that are subject to state supervision and regulation and allows scientifically substantiate the expediency or inexpediency of transition from an existing model of state regulation to another. The application of such innovative methods allowed to legislate the transition from the system of state regulation of financial services markets in EU countries from the sectoral model to the «megaregulator» model. The main features of each indicator are taken into account, which characterizes the state of business processes of the studied market and can be used for any other markets, in particular for the insurance markets of the countries of Central and Eastern Europe - Hungary, Slovakia, Poland, Czech Republic, etc.

Conclusion. In today's global conditions of state development it is necessary to evaluate the influence of information management on regulation of economic systems and their state. The search for innovative approaches to improving the areas of regulation and measures of influence on the development of systems, in particular financial, environmental, security, etc., was sought. In the scientific work, the innovative method for assessing the impact of the system's regulatory instruments on its state has been formed on the example of state regulation of the development of the insurance market of Ukraine for the period from 2005 to 2017. An interval scaling for assessment of the state of the insurance market by application of the «three sigma» rule has been performed on five levels: critical, low, satisfactory, medium, high, which allowed to determine the state of this market by defining the allowable boundary values of the indicators. Such a model of informational management can be used to assess business processes of any market or system to prove the existence of its innovative development. The hypotheses concerning the existence of causal relationships between the indicators characterizing business processes of the insurance market and the instruments of state regulation that can be quantified, are confirmed. This proof is realized through the application of a set of innovative models, in particular, those, which are the theoretical and practical basis for their possible use to solve the universal problem of modelling of causation processes for assessing the impact of the decisions made during any regulation of business processes.

Author Contributions: methodology, writing, R. B.; analysis and research, R. P.; conceptualization, editing, V. N.; visualization, formatting, S. H., curation of the Hungarian project, P. P. 
R. Bacho, R. Pukala, S. Hlibko, N. Vnukova, P. Pola. Information Management: the Key Driver of the Economic System's Development

\section{References}

Akaike, H. (1973). Information theory as an extension of the maximum likelihood principle. Petrov, B.N., Csaki, F. (Eds.) Second International Symposium on Information Theory. Budapest: Akademiai Kiado. (p.p. 267-281).

Arltova, M., \& Fedorova, D. (2016). Selection of Unit Root Test on the Basis of Length of the Time Series and Value of AR(1) Parameter. Statistika - Statistics and Economics Journal, 96, 47-67.

Burnham, K., Anderson, D. (2002). Model Selection and Multimodal Inference. New York: Springer.

Cihak, M., \& Podpiera, R. (2006). Is One Watchdog Better than Three? International Experience with Integrated FinancialSector Supervision. Czech Journal of Economics and Finance. Charles University Prague, Faculty of Social Sciences, 56(34), 102-126.

Chaddock, R. E. (1925). Principles and Methods of Statistics. Cambridge: Houghton Miffin Company, The Riverside Press.

Damodar, N.G. (2009). New York: Basic Econometrics, McGraw-Hill.

De Haan, J.; Oosterloo, S.; Schoenmaker, D. (2009). Cambridge: European Financial Markets and Institutions. Cambridge University Press.

Dickey, D.A., \& Fuller, W.A. (1981). Likelihood Ratio Statistics for Autoregressive Time Series with a Unit Root. Econometrica, 49, 1057-1072.

Dritsaki, M., Dritsaki, C., Adamopoulos, A. (2004) A Causal Relationship between Trade, Foreign Direct Investment and Economic Growth for Greece. American Journal of Applied Sciences, 1, 230-235.

Eichengreen, B., \& Dincer, N. (2011). Who Should Supervise? The Structure of Bank Supervision and the Performance of the Financial System. NBER Working Paper Series. Working Paper №17401.

Frantz, P., \& Instefjord, N. (2012). Financial regulation: regulatory arbitrage and regulatory harmonization. Social Science Research Network, 1-53

Gayawan, E., \& Ipinyomi, R., (2009). A Comparison of Akaike, Schwarz and R Square Criteria for Model Selection Using Some Fertility Models. Australian Journal of Basic and Applied Sciences, 3(4), 3524-3530.

Goodhart, C., \& Schoenmaker, D. (1995). Should the Functions of Monetary Policy and Banking Supervision Be Separated? Oxford Economic Papers. New Series, 47(4), 539-560.

Goodhart, C.A.E., \& Tsomocos, D.P. (2012). Cheltenham: Financial Stability in Practice. Edward Elgar Publishing.

Granger, C.W. J. (1974). Investigation Casual Relations by Econometric Methods and Cross-Spectal Methods. Econometrica, 37, 424-438.

Granger, C.W.J. (1983). Co-integrated variables and error-correcting models. San Diego: University of California, Department of Economics Working Paper, 83-113.

Hirtle, B., Schuermann, T., Stiroh, K. (2009) Macroprudential Supervision of Financial Institutions: Lessons from the SCAP.

New York: Federal Reserve Bank of New York Staff Reports № 409.

Hlibko S., Vnukova N., Hontar D., Anisimova H., Liubchych A. (2019) Risk-Oriented Approach to Determining Bank's Capital

Size according to Requirements of Basel Committee on Banking Supervision. Икономически изследвания, 28 (1), 56-71. Horakova, M., (2012). How countries Supervise their Banks, Insurers and Securities Markets. Central Banking Publications

(335 pages).

Ingves, S. (2011). Basel: Bank for International Settlements. Central Bank Governance and Financial Stability.

Johansen, S. (1991). Estimation and hypothesis testing of cointegration vectors in Gaussian vector autoregressive models.

Econometrica. Journal of the Econometric Society, 6, 1551-1580.

Kwiatkowski, D., Phillips, P.C.B., Schmidt, P., Shin Y. (1992). Testing the Null Hypothesis of Stationarity Against the

Alternative of a Unit Root. Journal of Econometrics, 54, 159-178.

Lebo, J.M., Kraft, W.P.(2017). The general error correction model in practice. Research and Politics, 2,1-17.

MacKinnon, J.C., Huag, A.A., Michelis, L. (1999). Numerical distribution functions of likelihood ratio tests for cointegration.

Journal of Applied Econometrics, 14, 563-577.

Masciandaro, D., \& Quintyn, M. (2009). After the Big Bang and Before the Next One? Reforming the Financial Supervision

Architecture and the Role of the Central Bank - A Review of Worldwide Trends, Causes and Effects (1998-2008). Italy: Paolo Baffi

Centre Research. Paper №2009-37.

Masciandaro, D., \& Quintyn, M. (2011). The Economic Crisis: Did Financial Supervision Matter? IMF Working Paper. No WP/11/261. November.

Melecky, M., \& Podpiera, A.M. (2012). Institutional Structures of Financial Sector Supervision, Their Drivers and Emerging Benchmark Models. MPRA Paper, №37059, 1-23.

Nier, E.W., Osinski, J., Jacome, L.I., Madrid, P. (2011). Towards Effective Macroprudential Policy Frameworks: an Assessment of Stylized Institutional Models. IMF Working Paper, WP/11/250.

Phillips, P.C.B., \& Perron, P. (1988). Testing for Unit Roots in Time Series Regression. Biometrika, 75, 335-346).

Ponomarenko V., Vnukova N., Kolodiziev O., Achkasova S. (2019) The influence of governmental regulation and supervision on the development of the risk-oriented system of financial monitoring of Ukraine. Financial and credit activity: problems of theory and practice, 29, 419-429. 
R. Bacho, R. Pukala, S. Hlibko, N. Vnukova, P. Pola. Information Management: the Key Driver of the Economic System's Development

Ren Z., Xiao, Z., Zhang, X. (2013). Two-step adaptive model selection for vector autoregressive processes. Journal of Multivariate Analysis, 116, 349-364

Schwarz, G. (1978). Estimating the dimension of a model. Ann Statist., 6, 461-464.

Sturgess, H.A. (1926). The choice of class intervals. Journal of American Statistical Association, 21, 153, 65-66.

Thadewald, T, \& Buning, H., (2007). Jarque-Bera Test and its Competitors for Testing Normality - A Power Comparison. Journal of Applied Statistics, 34(1), 87-105.

P. Бачо, D.SC., доцент, Ніредьгазський університет (Угорщина);

P. Пукала, Ph.D., Державна вища техніко-економічна школа ім. Кс. Броніслава Маркевича в Ярославі (Польща):

С. Глібко, д.ю.н., доцент, Науково-дослідний інститут забезпечення інноваційного розвитку Національної академіі правових наук України (Україна);

Н. Внукова, д.е.н., професор, Харківський національний економічний університет імені Семена Кузнеця (Україна);

П. Пола, Ph.D., Коледж Eotvos Jozsef, (Угорщина).

Інсормаційний менеджмент ключовий драйвер розвитку економічних систем

У науковій статті було розроблено інформаційну модель оцінки управління та впливу регуляторних інструментів на бізнеспроцеси на прикпаді страхового ринку України. Основна мета дослідження - визначити роль інформаційного менеджементу як кпючового рушія розвитку бізнес-процесів в економічних системах (на прикладі страхового ринку України). Систематизація літературних джерел та підходів до вирішення проблеми свідчить про те, що розробка інноваційних інструментів оцінки регуляторного впливу органу державного регулювання на бізнес-процеси страхового ринку не завершена і потребує більш поглибленого вивчення.Формування системи показників стану страхового ринку, які враховують вплив інструментів Регулятора, запропоновано реалізувати у такій послідовності: виявити наявність причинно-наслідкових зв'язків між показниками стану страхового ринку та заходами регулювання (впливу); визначити наявність реакції показників стану страхового ринку на заходи Регулятора з урахуванням розриву в часі, що обумовлюе наявності лагів у процесі застосування заходів Регулятора; означити та формалізувати змінність показників стану страхового ринку під впливом заходів Регулятора. $B$ результаті були сформульовані завдання щодо шкали стану страхового ринку: по-перше, перевірити на нормальність розподіл значень показників його стану; по-друге, побудувати відповідно до закону розподілу шкалу показників за правилом «трьох сигм»; по-третє, у разі невідповідності нормальному закону розподілу та наявності асиметрії можливе використання методу "трьох сигм», але за точку відліку береться або середне арифметичне, або мода варіаційного ряду, або його медіана. Актуальність рішення цієї наукової проблеми полягає в тому, що розроблено комплекс моделей для встановлення причиннонаслідкових залежностей між показниками, що характеризують стан страхового ринку та інструментами державного регулювання, які визначено кількісно, і $\epsilon$ теоретичною та практичною базою для можливого їх вживання для вирішення універсальних задач моделювання причинно-наслідкових процесів оцінки впливу прийнятих рішень під час будь-якого регулювання розвитку систембізнес-процесів. Для вирішення завдання проведено тест Грейнджера, розширений тест ДіккіФуллера, тест філліпса-Перрона та тест Квятковського-Філліпса-Шмідта-Шина. Виконано розподіл часових рядів за стаціонарністю, здійснена побудова моделей векторної авто регресії. Для оцінювання адекватності моделей використано порівняння значень критерію Фішера, Ст'юдента, коефіцієнта детермінації та скорегованого коефіцієнта детермінації. Для перевірки моделі на стаціонарність, стабільність використано критерії Jarque-Вега. Виконано формалізацію причиннонаслідкових зв'язків через постулат теорії вимірів і побудови шкал. Побудовані інтервальні шкали грунтуються на застосуванні правила «трьох сигм», що дозволило означити гранично допустимі значення показників. Отримані результати свідчать про вплив регуляторних інструментів на бізнес-процеси страхового ринку, що підтверджує правильність використання цього комплексу моделей для вирішення слабо формалізованих задач причинного характеру універсального типу. Запропонована інноваційна модель може бути використана як методологія розробки набору раціональних методів оцінки інформаційних впливів управлінських рішень у виробничих системах або маркетингових дослідженнях. Результати дослідження можуть бути використані для оцінки бізнес-процесів будь-якого ринку чи системи.

Ключові слова: бізнес-процеси, векторна авторегресія, інфоомаційний менеджмент, інфоормаційна модель, інструменти регулювання, ключовий драйвер, ринок страхових послуг, тест Грейнджера.

Manuscript received: 09.06.2019

(c) The author(s) 2019. This article is published with open access at Sumy State University. 